\title{
Effect of Copper and Magnesium Stoichiometric Additions and Thermal Aging on the Mechanical Properties of Cast Aluminium Alloys
}

\author{
Rakesh Kumar and Varinder Sahni
}

Department of Mechanical Engineering, Sant Longowal Institute of Engineering and Technology, Longowal (Deemed to be University), Sangrur - 148106, Punjab, India; rakeshsliet@yahoo.co.in, vsahni_2002@yahoo.co.in

\begin{abstract}
Objective: To study the mechanical properties of newly developed cast aluminium alloy with additions of copper and magnesium in the mole ratio of 1:1:1 of Al-Cu-Mg in as cast and thermally aged conditions. Methods/Statistical Analysis: For the (wt.\%) selection of Cu-Mg on the basis of stoichiometric calculations, 1 unit (wt.\%) of copper and 1 unit (wt. \%) of magnesium were mixed in base metal liquid. Aluminium 6063 base material was heated in an electric furnace at $750^{\circ} \mathrm{C}$ in permanent mild steel mould preheated at $200^{\circ} \mathrm{C}$ in order to achieve homogenised cast alloyed ingot. Findings: The specimens were extracted from cast aluminium ingot for tensile and impact strength evaluation, microhardness variations and metallurgical studies in as cast and aged conditions $\left(160^{\circ} \mathrm{C}\right.$ for 5,6 and 7 hours respectively). Optical microscopy reveals increased rate of intermetallic precipitation at aged conditions which was supported by X-ray diffraction patterns. Moreover, copper and magnesium additions increased the ultimate tensile strength, impact strength and microhardness values of newly developed aluminium cast alloy in comparison with conventional $\mathrm{Al} 6063$ base material. Application/ Improvement: Therefore, based upon the present work, it is recommended to use this ratio of copper and magnesium in aluminium base alloy in order to achieve better mechanical properties in industrial applications.
\end{abstract}

Keywords: Aluminum Alloys, Electric Furnace, Intermetallic Compounds, Solution Treatment, Thermal Aging

\section{Introduction}

Aluminium alloys are next to steels in use as structural metals. Its density is around $1 / 3$ to the steel which makes its use advantageous particularly for space vehicles, aircrafts as well as many types of surface and water borne vehicles 1 . In automobiles, the components such as engine blocks, head, pistons and wheels etc. are generally aluminium based cast alloys ${ }^{2}$. The low cost and scenario of continuous demands for weight reduction and improvements in fuel efficiency of automobiles have increased pace of research in developing aluminium based cast alloys ${ }^{3}$. The $\mathrm{Al}-\mathrm{Cu}-\mathrm{Mg}$ alloys offer high hardness and strength. Its components contribute the high degree of damage tolerance ${ }^{4}$. The alloys of the $\mathrm{Al}-\mathrm{Cu}-\mathrm{Mg}$ system provide the basis for the development of many other important $\mathrm{Al}$ alloys ${ }^{5}$. The composition of the alloying elements and casting conditions influence the state of intermetallic phases and finally the mechanical properties of the alloy ${ }^{6-8}$. The first age-hardening of aluminium alloy as reported in literature was performed in year 1909 who patented duralumin of casting components containing $\mathrm{Cu}$ and $\mathrm{Mg}$ substances?. The steps consist of solution treatment, quenching and artificial aging. The age -hardening mechanism is responsible for strengthening. The presence of copper in $\mathrm{Al}-\mathrm{Si}-\mathrm{Cu}$ alloys leads to the formation of the $\mathrm{Al} 2 \mathrm{Cu}$ intermetallic compounds has not dissolve during heat treatment $\frac{10-12}{}$.

The mechanism is based on the formation of intermetallic compounds during decomposition of a metastable

*Author for correspondence 
supersaturated solid solution by performing solution treatment and quenching $\frac{13-17}{}$. The copper and magnesium in combination have been used for improving the aging characteristic of the cast alloy 18 . Some of the investigators have taken compositions of alloying elements in weight fraction or volume fraction but in arbitrary manner. They have used design of experiments for material compositions as input parameters and different mechanical properties as responses, and finally optimum values of alloying elements are suggested for the given objective19. In place of taking the fraction of alloying element in arbitrary manner, a pattern based on stoichiometric weight fraction is explored and presented in the study. Study has been made on $\mathrm{Al}-\mathrm{Cu}-\mathrm{Mg}$ casting and results in terms of metallurgical and mechanical properties have been presented.

As per, $\mathrm{Al}-\mathrm{Cu}-\mathrm{Mg}$ alloys are in use with different ratios of addition of copper and magnesium but no work has been reported where stochiometric additions of 1:1:1 of $\mathrm{Al}: \mathrm{Cu}: \mathrm{Mg}$ was reported. Further, relation between metallurgical and mechanical properties of these aluminium alloys was not reported. Therefore, it was necessary to undertake present work in order to generate database for mechanical properties of these aluminium alloys.

\section{Experimentation}

\subsection{Methodology}

The mole ratio of $\mathrm{Al}-\mathrm{Cu}-\mathrm{Mg}$ was selected as 1:1:1 which resulted into the stoichiometric ratio of $\mathrm{Al}-\mathrm{Cu}-\mathrm{Mg}$ as 38.05-44.81-17.13. Such a high percentage of $\mathrm{Cu}$ and $\mathrm{Mg}$ cannot be a suitable condition for formation of the $\mathrm{Al}$ based alloy, hence $1 \%$ of wt. each of $\mathrm{Cu}$ and $\mathrm{Mg}$ as per stoichiometric ratio were taken for mixing with the base metal aluminium.

The aluminium was melted in a $2-\mathrm{kg}$ capacity of graphite crucible using an electric furnace. The temperature was maintained at $750^{\circ} \mathrm{C}$ for half an hour, which is higher than the melting temperature of $\mathrm{Al}$ as shown in
Table 1. The $\mathrm{Cu}$ and $\mathrm{Mg}$ in powder form were preheated at $250^{\circ} \mathrm{C}$ for 30 minutes and mixed in liquid aluminium metal which further stirred for five minutes at $800 \mathrm{rpm}$. The chemical compositions were tested using spark emission spectrometer analysis (Model No: Bruker Q8 Magellan, Make: Germany). The test method was used in accordance to ASTM E 415-2015 standards. Finally, metallographic and mechanical properties of the cast aluminium alloy are analysed.

The cast aluminium specimens were extracted as shown in Figure 1, polished as per standard metallographic procedure up to 3000 grit size and Kroll's etchant (Electrolyte used: Distilled water $(92 \mathrm{ml})+$ Nitric acid $(6 \mathrm{ml})+$ Hydrofluoric acid $(2 \mathrm{ml})$ was applied for 15 seconds to reveal microstructure using optical microscopy $^{20}$. The X-Ray Diffraction (XRD) technique (Make: Panalytical, Model: Xpert Pro) was used to generate spectra which showed intermetallic precipitation behaviour of cast base material and after alloying additions of copper and magnesium. Fractography studies were also performed to determine type of fractured surfaces for tensile and CVN samples of different aluminium cast ingots using Scanning Electron Microscopy (SEM) (Make:JEOL, Model:JSM-6510LV).

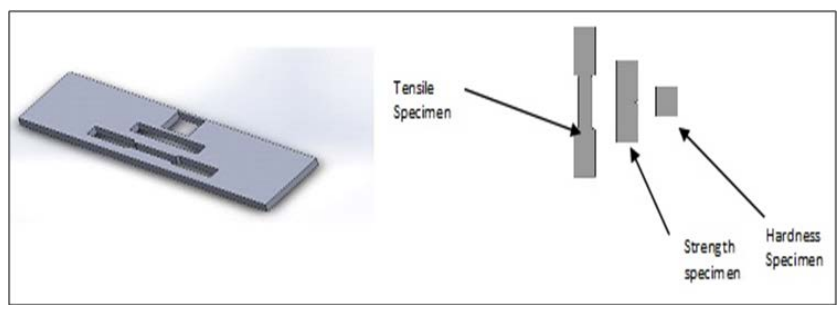

Figure 1. Schematic plan for extraction of specimens for metallurgical and mechanical testing.

Tensile specimens were tested on a servo hydraulic based digital controlled tensile testing machine of having capacity $50 \mathrm{kN}$ (make: Tinius Olsen, UK, Model-H50KS) and ultimate tensile strength for base and aged cast aluminium alloys were determined. The tensile specimens were prepared in accordance with ASTM E08/E8M-09

Table1. Furnace parameters for casting of aluminium alloys

\begin{tabular}{|l|l|l|l|l|l|l|}
\hline $\begin{array}{l}\text { Sl. } \\
\text { No. }\end{array}$ & Make/ Model & $\begin{array}{l}\text { Furnace } \\
\text { Temperature } \\
\text { Maintained }\end{array}$ & $\begin{array}{l}\text { Holding Time of } \\
\text { Liquidus Aluminium } \\
\text { at } 750^{\circ} \mathrm{C}\end{array}$ & $\begin{array}{l}\text { Mixing } \\
\text { Time }\end{array}$ & $\begin{array}{l}\text { Metal } \\
\text { Pouring } \\
\text { Time }\end{array}$ & $\begin{array}{l}\text { Thermal Aging } \\
\text { Temperature }\end{array}$ \\
\hline 1. & $\begin{array}{l}\text { Matrix Scientific } \\
\text { Instruments Pvt. } \\
\text { Ltd. Delhi }\end{array}$ & $750^{\circ} \mathrm{C}$ & $30 \mathrm{Mnts.}$ & $5 \mathrm{Mnts.}$ & $700^{\circ} \mathrm{C}$ & $1600 \mathrm{C}$ \\
\hline
\end{tabular}


(Sub size Specimen) standard21 as shown in Figure 2. The Charpy V-notch (CVN) test was done to measure the fracture toughness of cast and cast aged material. Figure 3 showed sample for Charpy V-notch test prepared as per ASTM E23-12c standard22.The hardness measurements were taken using Brinell hardness tester23 (make-: MIRAJ, INDIA, Model:3000(O) of maximum capacity $3000 \mathrm{Kgf}$. In this particular case the testing was carried out at $500 \mathrm{Kgf}$ load with a $5 \mathrm{~mm}$ indenter ball. The indentation was measured in terms of BHN fore cast and aged material.

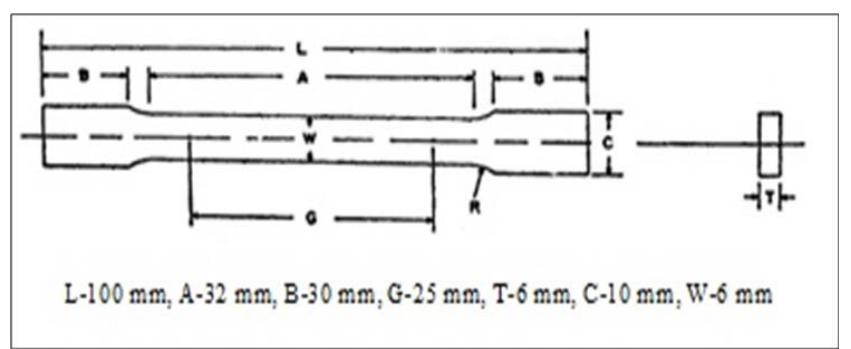

Figure 2. Dimensions of the tensile specimen as per ASTM standard.

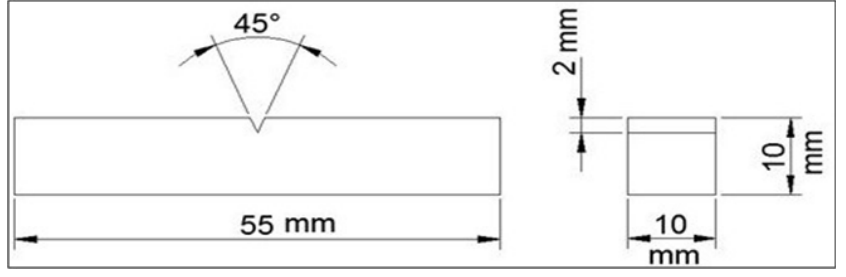

Figure 3. Schematic of the Charpy impact test specimen as per standard practice.

\section{Results and Discussion}

\subsection{Spectro Analysis}

Chemical composition of aluminium base material as purchased from local market was tested using spectrometer as shown in Table 2. Moreover, after alloying additions of copper and magnesium in aluminium matrix, chemical compositions were determined through spectrometer in as cast and aged conditions.

As evident from spectrometer analysis, on adding 1wt.\% (on stoichiometric basis as mentioned earlier)

Table 2. Chemical composition of base material

\begin{tabular}{|l|l|l|l|l|l|l|l|l|l|l|l|}
\hline $\mathrm{Al}$ & $\mathrm{Cu}$ & $\mathrm{Mg}$ & $\mathrm{Si}$ & $\mathrm{Mn}$ & $\mathrm{Ni}$ & $\mathrm{Zn}$ & $\mathrm{Pb}$ & $\mathrm{Cr}$ & $\mathrm{Fe}$ & $\mathrm{Sn}$ & $\mathrm{Ti}$ \\
\hline 98.78 & 0.0018 & 0.554 & 0.471 & 0.017 & 0.003 & 0.025 & 0.001 & 0.104 & 0.017 & 0.022 & 0.0042 \\
\hline
\end{tabular}

Table 3. Alloying element composition in cast and aged cast base material

\begin{tabular}{|c|c|c|c|c|c|c|}
\hline & $\mathrm{Al}$ & $\mathrm{Cu}$ & $\mathrm{Mg}$ & Si & Mn & $\mathrm{Ni}$ \\
\hline Cast base Aluminium & 98.52 & 0.0055 & 0.329 & 0.502 & 0.181 & 0.026 \\
\hline $\begin{array}{l}\text { 1Hrs solution Treatment \& } 5 \mathrm{Hrs} \text { Aged- } \\
\text { cast base Aluminium with } 1 \% \mathrm{Cu}, \mathrm{Mg}\end{array}$ & 98.11 & 0.281 & 0.164 & 0.631 & 0.41 & 0.008 \\
\hline $\begin{array}{l}2 \text { Hrs solution Treatment \& } 6 \text { Hrs } \\
\text { Aged- cast base Aluminium with } 1 \% \\
\mathrm{Cu}, \mathrm{Mg}\end{array}$ & 95.41 & 0.543 & 0.305 & 0.737 & 0.9 & 0.27 \\
\hline \multirow[t]{2}{*}{$\begin{array}{l}3 \text { Hrs solution Treatment \& } 7 \text { Hrs } \\
\text { Aged- cast base Aluminium with } 1 \% \\
\mathrm{Cu}, \mathrm{Mg}\end{array}$} & 95.45 & 0.542 & 0.306 & 0.73 & 0.92 & 0.32 \\
\hline & $\mathrm{Zn}$ & $\mathrm{Pb}$ & $\mathrm{Cr}$ & $\mathrm{Fe}$ & Sn & $\mathrm{Ti}$ \\
\hline Cast base Aluminium & 0.064 & 0.173 & 0.152 & 0.013 & 0.028 & 0.0065 \\
\hline $\begin{array}{l}\text { 1Hrs solution Treatment \& } 5 \mathrm{Hrs} \text { Aged- } \\
\text { cast base Aluminium with } 1 \% \mathrm{Cu}, \mathrm{Mg}\end{array}$ & 0.063 & 0.051 & 0.008 & 0.24 & 0.01 & 0.024 \\
\hline $\begin{array}{l}2 \text { Hrs solution Treatment \& } 6 \mathrm{Hrs} \\
\text { Aged- cast base Aluminium with } 1 \% \\
\mathrm{Cu}, \mathrm{Mg}\end{array}$ & 0.74 & 0.14 & 0.005 & 0.64 & 0.19 & 0.12 \\
\hline $\begin{array}{l}3 \text { Hrs solution Treatment \& } 7 \text { Hrs } \\
\text { Aged- cast base Aluminium with } 1 \% \\
\mathrm{Cu}, \mathrm{Mg}\end{array}$ & 0.074 & 0.62 & 0.008 & 0.52 & 0.28 & 0.23 \\
\hline
\end{tabular}


copper and magnesium in the base material, there is increase in the percentages of both alloying additions in aluminium matrix. However, there were no variation in elemental compositions when samples were aged as shown in Table 3, reduction aluminium percentage in the matrix was also noticed which is quite evident with addition of copper and magnesium.

\subsection{XRD Spectra}

There is formation of intermetallic precipitates on melting. Table 4 shows presence of intermetallic precipitates in cast base material and cast aluminium alloy with copper and magnesium addition in as cast and thermally aged conditions which has been observed in XRD spectra. In cast base material $\mathrm{Al} 6063, \mathrm{AlCu}$ compound has less strength and $\mathrm{Al}_{12} \mathrm{Mg}_{17}$ compound contributes to hardness of cast alloy. However, when aging was done to $160^{\circ} \mathrm{C}$, formation of $\mathrm{Al}_{5} \mathrm{Cu}_{6} \mathrm{Mg}$ sigma phase takes place which increases the tensile strength of the material. At the elevated temperature coarse precipitate $\mathrm{AlCuMg}$ was also formed. The aging treatment dissolves the $\mathrm{AlCu}$ compound and forms complex precipitate compounds which enhance the strength of the matrix. Alloyed with 1 wt \% (on stoichiometric basis as mentioned earlier) of copper and magnesium, complex precipitates were observed in XRD spectra shown in Figure 4 which increases the microhardness and tensile strength of the aluminium alloys. At elevated temperature, alloyed metal matrix composite with copper and magnesium, dissolution of these complex compounds occurs and formation of coarse precipitates such as $\mathrm{Al}_{2} \mathrm{CuMg}^{3}$ and $\mathrm{Al}_{14} \mathrm{Mg}_{13}$ was there which enhances the toughness and strength at high temperatures. Sigma phase precipitation was noticed in as cast and aged aluminium alloyed with copper and magne- sium which enhances their strength as compared to cast base material.
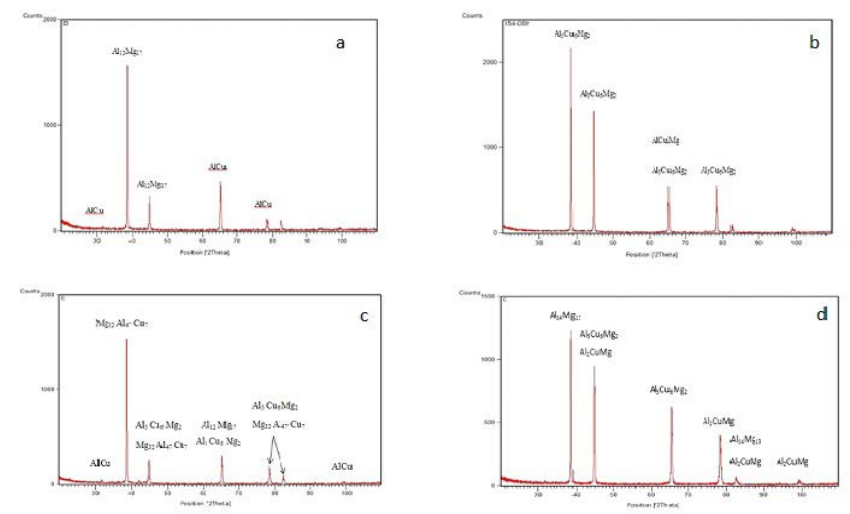

Figure 4. Intermetallic precipitate formation as per XRD diffraction patterns for: (a) Cast base Aluminium, (b)1Hrs solution Treatment \& $5 \mathrm{Hrs}$ Aged- cast base Aluminium with $1 \% \mathrm{Cu}, \mathrm{Mg}$, (c) 2 Hrs solution Treatment \& 6 Hrs Aged- cast base Aluminium with $1 \% \mathrm{Cu}, \mathrm{Mg}$, and (d) $3 \mathrm{Hrs}$ solution Treatment \& 7 Hrs Aged- cast base Aluminium with $1 \% \mathrm{Cu}$, $\mathrm{Mg}$

\subsection{Microstructural Studies}

The photograph of microstructures of Cast base Aluminium, 1Hrs solution Treatment \& 5Hrs Agedcast base Aluminium with $1 \% \mathrm{Cu}, \mathrm{Mg}, 2 \mathrm{Hrs}$ solution Treatment \& 6 Hrs Aged- cast base Aluminium with 1\% $\mathrm{Cu}, \mathrm{Mg}$ and 3 Hrs solution Treatment \& 7 Hrs Aged- cast base Aluminium with $1 \% \mathrm{Cu}, \mathrm{Mg}$ are shown in Figure 5. There was negligible precipitate formation along the grain boundaries in cast base material but after aging, nucleation of precipitates at most of the grain boundaries were noticed which enhances the strength. Alloying with copper and magnesium leads to fine precipitate forma-

Table 4. Intermetallic compounds in cast and aged condition as per XRD spectra

\begin{tabular}{|l|l|l|l|l|}
\hline Type of material & \multicolumn{4}{|l|}{ Intermetallic precipitate formation as per XRD spectra } \\
\hline Cast base Aluminium & $\mathrm{AlCu}$ & $\mathrm{Al}_{12} \mathrm{Mg}_{17}$ & - & - \\
\hline $\begin{array}{l}1 \mathrm{Hrs} \text { solution Treatment \& } 5 \mathrm{Hrs} \\
\text { Aged- cast base Aluminium with } \\
1 \% \mathrm{Cu}, \mathrm{Mg}\end{array}$ & $\mathrm{Al}_{5} \mathrm{Cu}_{6} \mathrm{Mg}$ & $\mathrm{AlCuMg}$ & - & - \\
\hline $\begin{array}{l}2 \mathrm{Hrs} \text { solution Treatment \& } 6 \mathrm{Hrs} \\
\text { Aged- cast base Aluminium with } \\
1 \% \mathrm{Cu}, \mathrm{Mg}\end{array}$ & $\mathrm{AlCu}$ & $\mathrm{Al}_{12} \mathrm{Mg}_{17}$ & $\mathrm{Al}_{5} \mathrm{Cu}_{6} \mathrm{Mg}$ & $\mathrm{Al}_{47} \mathrm{Mg}_{32} \mathrm{Cu}_{7}$ \\
\hline $\begin{array}{l}3 \mathrm{Hrs} \text { solution Treatment \& } 7 \mathrm{Hrs} \\
\text { Aged- cast base Aluminium with } \\
1 \% \mathrm{Cu}, \mathrm{Mg}\end{array}$ & $\mathrm{Al}_{5} \mathrm{Cu}_{6} \mathrm{Mg}$ & $\mathrm{Al}_{2} \mathrm{CuMg}$ & $\mathrm{Al}_{14} \mathrm{Mg}_{13}$ & - \\
\hline
\end{tabular}


tion. However, as aging was done, these fine precipitates transform to coarser precipitates at high temperature and nucleation at grain boundaries were enhanced.

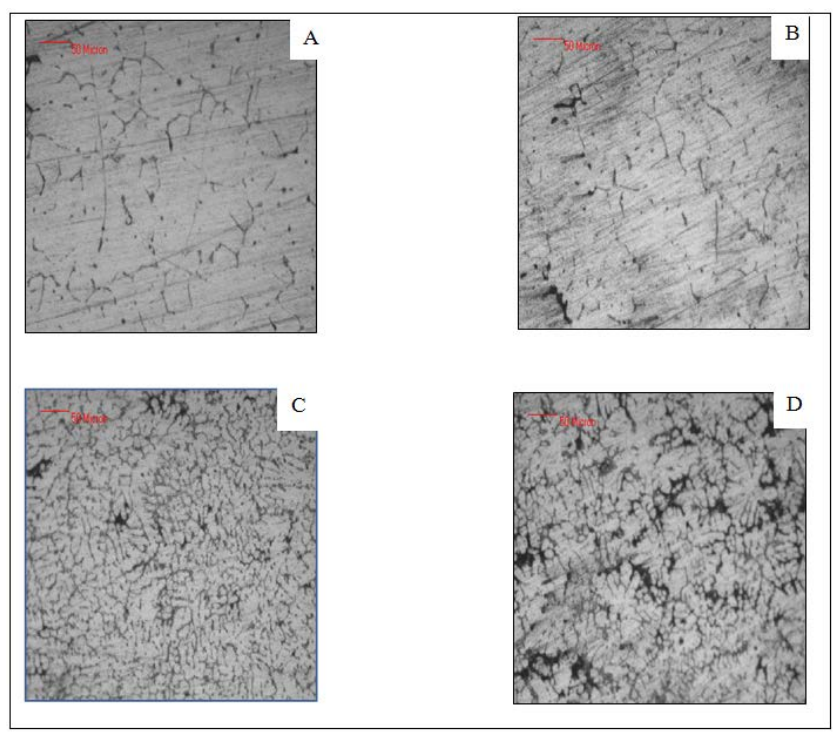

Figure 5. Photomicrographs at 200X for: (a) Cast base Aluminium, (b) $1 \mathrm{Hrs}$ solution Treatment \& 5Hrs Agedcast base Aluminium with $1 \% \mathrm{Cu}, \mathrm{Mg}$, (c) 2 Hrs solution Treatment \& 6 Hrs Aged- cast base Aluminium with $1 \% \mathrm{Cu}$, $\mathrm{Mg}$, and (d) 3 Hrs solution Treatment \& 7 Hrs Aged- cast base Aluminium with $1 \% \mathrm{Cu}, \mathrm{Mg}$.

\subsection{Tensile and Microhardness Studies}

Tensile strength and microhardness values of cast metal at different stages are shown in Table 5. Their tensile fractographs are shown in Figure 6. Dimple morphology was observed in the fractographs. In cast base metal, small dimples comprising of precipitates were observed but after aging of this cast base, the small dimples coalesce together to form large dimples which contain hardened precipitates ${ }^{24}$. These hardened participates contribute to increase in ultimate tensile strength of the aged cast. Copper and magnesium act as inoculants when alloyed with aluminium base metal and induce grain refining in matrix by nucleating more nucleation sites for precipitation. Thus, precipitation hardening was induced in alloyed metal matrix while casting which improves the ultimate tensile strength of cast metal. As the strength increases it also increases microhardness of copper, magnesium added cast metal.
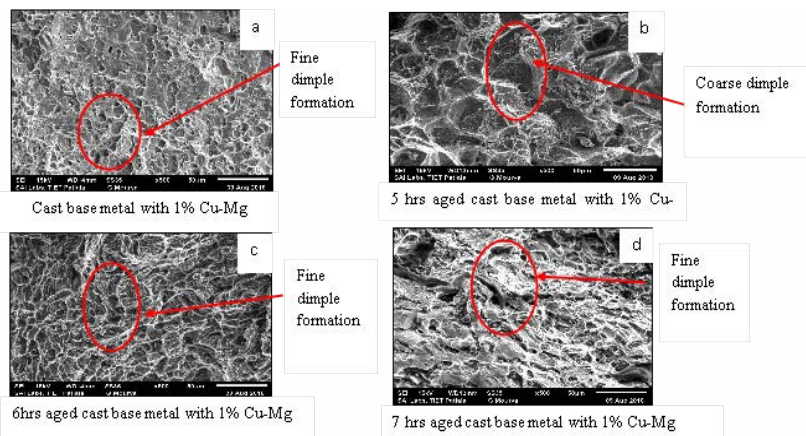

Figure 6. Tensile fractographs at 500X for: (a) Cast base Aluminium, (b) 1 Hrs solution Treatment \& 5Hrs Agedcast base Aluminium with $1 \% \mathrm{Cu}, \mathrm{Mg}$, (c) 2 Hrs solution Treatment \& 6 Hrs Aged- cast base Aluminium with $1 \% \mathrm{Cu}$, $\mathrm{Mg}$, and (d) 3 Hrs solution Treatment \& 7 Hrs Aged- cast base Aluminium with $1 \% \mathrm{Cu}, \mathrm{Mg}$.

\subsection{Impact Studies}

The results of impact strength in terms of joules of energy to estimate fracture toughness of cast materials was shown in Table 6 and their impact fractographs are shown in Figure 7. In cast base metal, dimple fracture was noticed which corresponds to ductile fracture. When alloyed with copper and magnesium, cast aluminium base metals pos-

Table 5. Microhardness and ultimate tensile strength values of cast base and metal matrix alloyunder as cast and aged condition

\begin{tabular}{|l|l|l|l|l|}
\hline $\begin{array}{l}\text { Sl. } \\
\text { No. }\end{array}$ & Type of material & $\begin{array}{l}\text { Area of Tensile Test } \\
\text { specimen, } \mathbf{~ m m}^{2}\end{array}$ & $\begin{array}{l}\text { Ultimate } \\
\text { Tensile Strength } \\
\left(\mathbf{N} / \mathbf{m m}^{2}\right)\end{array}$ & $\begin{array}{l}\text { Microhardness on } \\
\text { Vicker's scale at load- } \\
\text { 300 gms, Time-20sec. }\end{array}$ \\
\hline 1. & Cast base Aluminium with $1 \% \mathrm{Cu}, \mathrm{Mg}$ & 36 & 142 & 540 \\
\hline 2. & $\begin{array}{l}1 \text { Hrs solution Treatment \& } 5 \mathrm{Hrs} \text { Aged- cast } \\
\text { base Aluminium with } 1 \% \mathrm{Cu}, \mathrm{Mg}\end{array}$ & 36 & 200 & 83.67 \\
\hline 3. & $\begin{array}{l}\text { 2 Hrs solution Treatment \& } 6 \mathrm{Hrs} \text { Aged- } \\
\text { cast base Aluminium with } 1 \% \mathrm{Cu}, \mathrm{Mg}\end{array}$ & 36 & 188 & 76.80 \\
\hline 4. & $\begin{array}{l}\text { 3 Hrs solution Treatment \& 7 Hrs Aged- } \\
\text { cast base Aluminium with } 1 \% \mathrm{Cu}, \mathrm{Mg}\end{array}$ & 36 & 173 & 58.30 \\
\hline
\end{tabular}


sess very small dimples (Figure 6c) because of refinement of grain structure of base metal which ultimately improves the fracture toughness of material $\stackrel{19}{ }$. At thermally aged conditions, metal matrix alloyed cast metal; intermetallic precipitates as shown in XRD patterns improves significantly toughness of alloyed cast base material.

Table 6.Impact strength values of cast base and Metal matrix alloy in as cast and aged condition

\begin{tabular}{|l|l|l|}
\hline $\begin{array}{l}\text { Sl. } \\
\text { No. }\end{array}$ & Type of material & $\begin{array}{l}\text { Impact Strength } \\
\text { (joules) }\end{array}$ \\
\hline 1. & Cast base Aluminium 1\% Cu, Mg & 15 \\
\hline 2. & $\begin{array}{l}1 \mathrm{Hrs} \text { solution Treatment \& 5Hrs } \\
\text { Aged- cast base Aluminium with } \\
1 \% \mathrm{Cu}, \mathrm{Mg}\end{array}$ & 17 \\
\hline 3. & $\begin{array}{l}\text { 2 Hrs solution Treatment \& 6 Hrs } \\
\text { Aged- cast base Aluminium with } \\
1 \% \mathrm{Cu}, \mathrm{Mg}\end{array}$ & 19 \\
\hline 4. & $\begin{array}{l}3 \mathrm{Hrs} \text { solution Treatment \& 7 Hrs } \\
\text { Aged- cast base Aluminium with } \\
1 \% \mathrm{Cu}, \mathrm{Mg}\end{array}$ & 24 \\
\hline
\end{tabular}

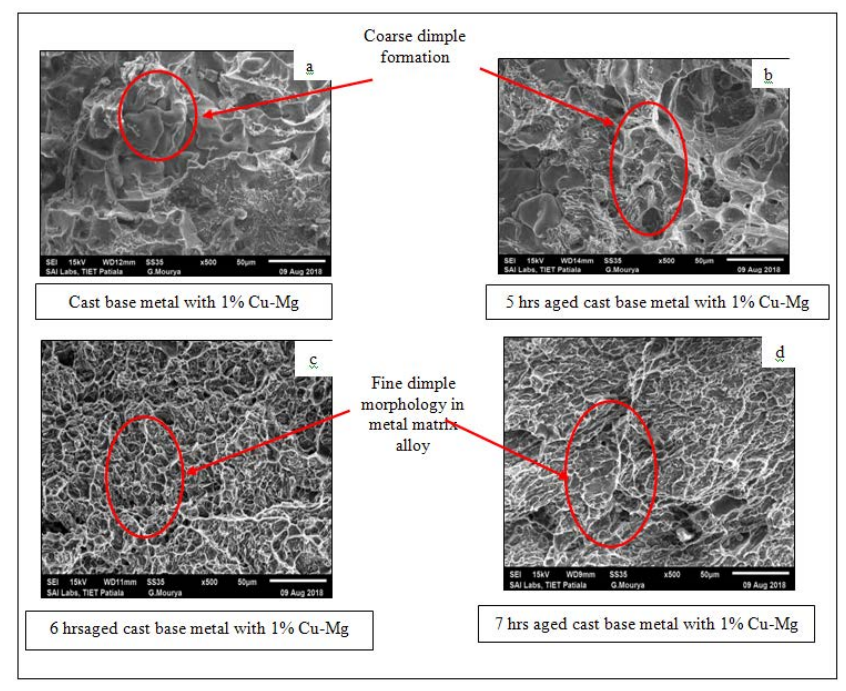

Figure 7. Fractographs of impact specimens at 500X for(a) Cast base Aluminium, (b) $1 \mathrm{Hrs}$ solution Treatment \& $5 \mathrm{Hrs}$ Aged- cast base Aluminium with $1 \% \mathrm{Cu}, \mathrm{Mg}$, (c) $2 \mathrm{Hrs}$ solution Treatment \& 6 Hrs Aged- cast base Aluminium with $1 \% \mathrm{Cu}, \mathrm{Mg}(\mathrm{d}) 3 \mathrm{Hrs}$ solution Treatment \& 7 Hrs Agedcast base Aluminium with $1 \% \mathrm{Cu}, \mathrm{Mg}$.

\section{Conclusion}

- With increase in aging time of copper and magnesium added aluminium cast base metal, different intermetallic precipitation behaviour was observed as compared to cast base metal in as cast condition as observed from XRD studies,

- Owing to increased intermetallic precipitation at aged conditions as revealed by optical microscopy, significant improvement in mechanical properties was noticed viz. ultimate tensile strength, impact strength and microhardness, and

- Further, ductile fracture with dimple formations was observed in all specimens.

\section{Acknowledgements}

This work was carried out with the financial support from Sant Longowal Institute of Engineering and Technology, Longowal under Ministry of Human Resource Development, Government of India. The XRD facilities of IIT Ropar and SEM facilities of SAI labs, Thapar University Patiala were used to record metallurgical morphology of specimen.

\section{References}

1. DavisJR. Alloying: understanding the basics.ASM International Publication; 2001. p. 1-647.

2. Brown JR. Foseco Non-ferrous foundry's hand book. Butterworth Heinemann Publication; 1999. p. 1-304. https://doi.org/10.1016/B978-075064286-6/50002-4.

3. Cui S, Mishra R, Jung IH. Thermodynamic analysis of 6xxx Series AL Alloys: Phase Fraction Diagrams, Journal of Mining and Metallurgy Section B: Metallurgy. 2018; 54(1):119-131. https://doi.org/10.2298/JMMB170512052C.

4. Feng W, Yanqi Z, Baiqing X, Yongan Z, Xiwu L, Zhihui L, Hongwei L. Effect of Si addition on the microstructure and mechanical properties of $\mathrm{Al}-\mathrm{Cu}-\mathrm{Mg}$ alloy, Journal of Alloys and Compounds. 2014; 585:474-78. https://doi. org/10.1016/j.jallcom.2013.08.214.

5. Hutchinson CR, Ringer SP. Precipitation processes in Al-Cu-Mg Alloys Micro alloyed with Si, Metallurgical and Materials Transactions A. 2000; 31(11):2721-33. https:// doi.org/10.1007/BF02830331.

6. Imam MFIA, Rahman MS, Khan MZH. Influence of heat treatment on fatigue and fracture behaviour of aluminium alloy, Journal of Engineering Science and Technology. 2015; 10(6):730-42.

7. Wang ER, Hui XD, Chen GL. Eutectic Al-Si-Cu-Fe-Mn alloys with enhanced mechanical properties at room and elevated temperature, Materials and Design. 2011; 32(89):4333-40. https://doi.org/10.1016/j.matdes.2011.04.005.

8. Ramesh CS, Ahamed A. Friction and wear behaviour of cast Al 6063 based in situ metal matrix composites, 
Wear. 2011; 271(9-10):1928-39. https://doi.org/10.1016/j. wear.2010.12.048.

9. Polmear IJ. Aluminium alloys-A century of Age Hardening, Materials Forum. 2004. 28:1-14. PMCid: PMC324500.

10. Zeren M, Karakulak E, Gumus S. Influence of $\mathrm{Cu}$ addition on microstructure and hardness of near-eutectic Al-SixCu-alloys, Transactions of Nonferrous Metals Society of China. 2011; 21(8):1698-702. https://doi.org/10.1016/ S1003-6326(11)60917-5.

11. Ibrahim S, Shamah AM, Hanna FF, Marei LK. Formation of nanoquasicrystalline phases by mechanical allowing of ternary systems Al86Cr8Fe6 and Al62.5 Cu25Fe12.5, Australian Journal of Basic and Applied Sciences. 2011; 5(5):375-85.

12. Ibrahim MF, Samuel E, Samuel AM, Al-Ahmari AMA, Samuel FH. Metallurgical parameters controlling the microstructure and hardness and hardness of Al-Si-Cu-Mg base alloys, Materials and Design. 2011; 32(4):2130-42. https://doi.org/10.1016/j.matdes.2010.11.040.

13. Sjolander E, Seifeddine S. Artificial ageing of Al-Si$\mathrm{Cu}-\mathrm{Mg}$ casting alloys, Materials Science and Engineering: A. 2011. 528(24):7402-09. https://doi.org/10.1016/j. msea.2011.06.036.

14. Oladele IO, Omotoyinbo JA. Evaluating the influence of ageing temperature on the mechanical properties of Al-Mg-Si Alloy, Journal of Minerals and Materials Characterization and Engineering. 2011; 10(14):1285-92. https://doi.org/10.4236/jmmce.2011.1014101.

15. Sjolander E, Seifeddine S. Optimal of solution treatment of cast Al-Si-Cu alloys, Materials and Design. 2010; 31:544-49.

16. Ma Z, Samuel E, Mohamed AMA, Samuel AM, Samuel FH, Doty HW. Parameters controlling the microstructure of $\mathrm{Al}-11 \mathrm{Si}-2.5 \mathrm{Cu}-\mathrm{Mg}$ alloys, Materials and Design. 2010; 31(2):902-12. https://doi.org/10.1016/j.matdes.2009.07.033.

17. Toda H, NishimuraT, Uesugi K, Suzuki Y, Kobayashi M. Influence of high-temperature solution treatments on mechanical properties of an $\mathrm{Al}-\mathrm{Si}$-Cu aluminum alloy, Acta Materialia. 2010; 58(6):2014-25. https://doi.org/10.1016/j. actamat.2009.11.044.

18. Sjolander E, Seifeddine S. The heat treatment of Al-Si$\mathrm{Cu}-\mathrm{Mg}$ casting alloys, Journal of Materials Processing Technology. 2010; 10(1):1249-59. https://doi.org/10.1016/j. jmatprotec.2010.03.020.

19. Grosselle F, Timelli G, Bonollo F. Doe applied to microstructural and mechanical properties of $\mathrm{Al}-\mathrm{Si}-\mathrm{Cu}-\mathrm{Mg}$ casting alloys for automotive applications, Materials Science and Engineering: A. 2010; 527(15):3536-45. https://doi. org/10.1016/j.msea.2010.02.029.

20. ASTM E47-7, Standard practice for micro etching metals and alloys. ASTM International; 2007. p. 1-23.

21. ASTM E8/E8MStandard test methods for tension testing of metallic materials. Date accessed: 01/08/2016. https://global. ihs.com/doc_detail.cfm?document_name=ASTM\%20 E8\%2FE8M\&item_s_key=00505317.

22. ASTM E23-12c, Standard test methods for notched bar impact testing of metallic materials. ASTM International; p. $1-25$.

23. ASTM E-10-15, Standard test methods for Brinell hardness of materials, ASTM International; p. 1-32.

24. Su-ling C, Gen-cang Y, Man Z, Jin-cheng W, Yao-he Z. Mechanical properties and fracture mechanisms of aluminum matrix composites reinforced by Al9 (Co, Ni)2 intermetallics, Transactions of Nonferrous Metals Society of China. 2010; 20(4):572-76. https://doi.org/10.1016/ S1003-6326(09)60180-1. 